\title{
1 Remdesivir for the treatment of COVID-19: A living
}

\section{2 systematic review}

3 Verdugo-Paiva $\mathrm{F}^{1,2}$, Acuña $\mathrm{P}^{3,4}$, Sola $\mathrm{I}^{5,6,7}$, Rada $\mathrm{G}^{1,2}$. COVID-19 L-OVE Working Group

4

5 1. Epistemonikos Foundation, Santiago, Chile

6 2. UC Evidence Center, Cochrane Chile Associated Center, Pontificia Universidad Católica de Chile, Santiago, Chile

7 3. Unidad de Infectología, Hospital Dr Sótero del Río, Santiago, Chile

8 4. Unidad de Infectología, Hospital Clínico Dra Eloísa Díaz, La Florida, Santiago, Chile

9 5. Biomedical Research Institute Sant Pau, Barcelona, Spain

10 6. Iberoamerican Cochrane Centre, Barcelona, Spain

7. CIBER Epidemiología y Salud Pública (CIBERESP)

\section{Abstract}

Objective

This living systematic review aims to provide a timely, rigorous and continuously updated summary of the evidence available on the role of remdesivir in the treatment of patients with COVID-19.

\section{Methods}

We adapted an already published common protocol for multiple parallel systematic reviews to the specificities of this question.

Eligible studies were randomised trials evaluating the effect of remdesivir versus placebo or no treatment.

We conducted searches in the L.OVE (Living OVerview of Evidence) platform for COVID-19, a system that maps PICO questions to a repository maintained through regular searches in electronic databases, preprint servers, trial registries and other resources relevant to COVID-19. All the searches covered the period until 25 August 2020. No date or language restrictions were applied. Two reviewers independently evaluated potentially eligible studies according to predefined selection criteria, and extracted data on study characteristics, methods, outcomes, and risk of bias, using a predesigned, standardised form.

We performed meta-analyses using random-effect models and assessed overall certainty in evidence using the GRADE approach.

A living, web-based version of this review will be openly available during the COVID-19 pandemic. We will resubmit it every time the conclusions change or whenever there are substantial updates. 
medRxiv preprint doi: https://doi.org/10.1101/2020.09.27.20202754; this version posted September 28, 2020. The copyright holder for this preprint (which was not certified by peer review) is the author/funder, who has granted medRxiv a license to display the preprint in It is made available under a CC-BY-NC-ND 4.0 International license .

Results

Our search strategy yielded 574 references. Finally, we included 3 randomised trials evaluating remdesivir in addition to standard care versus standard care alone. The evidence is very uncertain about the effect of remdesivir on mortality ( $\mathrm{RR} 0.7,95 \% \mathrm{Cl} 0.46$ to 1.05 ; very low certainty evidence) and the need for invasive mechanical ventilation ( $\mathrm{RR} 0.69,95 \% \mathrm{Cl} 0.39$ to 1.24 ; very low certainty evidence). On the other hand, remdesivir likely results in a large reduction in the incidence of adverse effects in patients with COVID-19 (RR 1.29, 95\% Cl 0.58 to 2.84; moderate certainty evidence).

\section{Conclusions}

The evidence is insufficient for the outcomes critical for making decisions about the role of remdesivir in the treatment of patients with COVID-19, so it is not possible to balance the potential benefits, if any, with the adverse effects and costs.

\section{PROSPERO Registration number}

CRD42020183384

51

\section{Keywords}


medRxiv preprint doi: https://doi.org/10.1101/2020.09.27.20202754; this version posted September 28, 2020. The copyright holder for this preprint (which was not certified by peer review) is the author/funder, who has granted medRxiv a license to display the preprint in

It is made available under a CC-BY-NC-ND 4.0 International license .

\begin{tabular}{|c|c|c|c|c|c|c|}
\hline \multicolumn{7}{|c|}{ Remdesivir for the treatment of COVID-19 } \\
\hline Patients & \multicolumn{6}{|c|}{ Confirmed COVID-19 } \\
\hline Intervention & \multicolumn{6}{|c|}{ Remdesivir \pm standard treatment (as defined by the studies) } \\
\hline Comparison & \multicolumn{6}{|c|}{ Placebo or no treatment \pm standard treatment (as defined by the studies) } \\
\hline \multirow{2}{*}{ Outcomes } & \multirow{2}{*}{$\begin{array}{l}\text { Relative effect } \\
\qquad(95 \% \mathrm{CI}) \\
\text {-- } \\
\text { Patients/ studies }\end{array}$} & \multicolumn{3}{|c|}{ Absolut effect* } & \multirow{2}{*}{$\begin{array}{l}\text { Certainty of } \\
\text { evidence } \\
\text { (GRADE) }\end{array}$} & \multirow{2}{*}{ Key messages } \\
\hline & & $\begin{array}{l}\text { WITHOUT } \\
\text { Remdesivir }\end{array}$ & $\begin{array}{l}\text { WITH } \\
\text { Remdesivir }\end{array}$ & $\begin{array}{l}\text { Difference } \\
\text { (Cl 95\%) }\end{array}$ & & \\
\hline All-cause mortality & $\begin{array}{c}\text { RR } 0.7 \\
(0.46 \text { to } 1.05) \\
1879 \text { patients in } 3 \\
\text { studies }[24,25,26]\end{array}$ & $\begin{array}{c}85 \\
\text { per } 1000\end{array}$ & $\begin{array}{c}60 \\
\text { per } 1000\end{array}$ & $\begin{array}{c}26 \text { less } \\
\text { (34 less to } 4 \\
\text { more) }\end{array}$ & $\begin{array}{c}\bigoplus \circ \circ \circ \\
\text { Very low (1) }\end{array}$ & $\begin{array}{l}\text { The evidence is very } \\
\text { uncertain about the effect of } \\
\text { remdesivir on mortality in } \\
\text { patients with COVID-19 }\end{array}$ \\
\hline $\begin{array}{l}\text { Invasive mechanical } \\
\text { ventilation }\end{array}$ & $\begin{array}{c}\text { RR } 0.69 \\
(0.39 \text { to } 1.24) \\
1659 \text { patients in } 3 \\
\text { study }[24,25,26]\end{array}$ & $\begin{array}{c}116 \\
\text { per } 1000\end{array}$ & $\begin{array}{c}80 \\
\text { per } 1000\end{array}$ & $\begin{array}{l}36 \text { less } \\
\text { (44 less to } 6 \\
\text { more) }\end{array}$ & $\begin{array}{c}\bigoplus \circ \circ \circ \\
\text { Very low (2) }\end{array}$ & $\begin{array}{l}\text { The evidence is very } \\
\text { uncertain about the effect of } \\
\text { remdesivir on the need for } \\
\text { invasive mechanical } \\
\text { ventilation in patients with } \\
\text { COVID-19 }\end{array}$ \\
\hline $\begin{array}{l}\text { Adverse effects } \\
\text { leading to } \\
\text { discontinuation }\end{array}$ & $\begin{array}{c}\text { RR } 1.29 \\
(0.58 \text { to } 2.84) \\
1296 \text { patients in } 2 \\
\text { study }[24,25]\end{array}$ & $\begin{array}{c}67 \\
\text { per } 1000\end{array}$ & $\begin{array}{c}86 \\
\text { per } 1000\end{array}$ & $\begin{array}{l}19 \text { more } \\
\text { (36 less to } 3 \\
\text { more) }\end{array}$ & $\begin{array}{c}\oplus \oplus \bigoplus \circ \\
\text { Moderate (3) }\end{array}$ & $\begin{array}{l}\text { Remdesivir likely results in a } \\
\text { large reduction in the } \\
\text { incidence of adverse effects }\end{array}$ \\
\hline $\begin{array}{l}\text { Time to viral } \\
\text { clearance }\end{array}$ & -- & $\begin{array}{l}\text { Not } \\
\text { reported }\end{array}$ & -- & -- & (4) & $\begin{array}{l}\text { This outcome was not } \\
\text { measured or reported by the } \\
\text { included studies }\end{array}$ \\
\hline $\begin{array}{l}\text { Length of hospital } \\
\text { stay }\end{array}$ & $\begin{array}{c}\text { MD } 1 \\
(-2.86 \text { to } 4.86) \\
236 \text { patients in } 1 \\
\text { study [25] }\end{array}$ & 24 days & 23 days & $\begin{array}{c}1 \text { day less } \\
\text { (6 days less to } \\
3 \text { days more) }\end{array}$ & $\begin{array}{l}\bigoplus \bigoplus \circ \circ \\
\text { Low (5) }\end{array}$ & $\begin{array}{l}\text { Remdesivir may result in little } \\
\text { to no difference in the } \\
\text { duration of hospitalisation }\end{array}$ \\
\hline $\begin{array}{c}\text { Serious adverse } \\
\text { effects }\end{array}$ & $\begin{array}{c}\text { RR } 0.74 \\
(0.62 \text { to } 0.9) \\
1880 \text { patients in } 3 \\
\text { study }[24,25,26]\end{array}$ & $\begin{array}{c}224 \\
\text { per } 1000\end{array}$ & $\begin{array}{c}166 \\
\text { per } 1000\end{array}$ & $\begin{array}{c}58 \text { less } \\
\text { (85 less to } 22 \\
\text { more) }\end{array}$ & $\begin{array}{c}\oplus \oplus \bigoplus \circ \\
\text { Moderate (7) }\end{array}$ & $\begin{array}{c}\text { Remdesivir likely reduces the } \\
\text { number of serious adverse } \\
\text { effects }\end{array}$ \\
\hline
\end{tabular}

Cl: confidence interval; RR: Risk ratio; MD: Mean difference; GRADE: Grading of Recommendations Assessment, Development and Evaluation.

*Other trial reported length of hospital stay, but data was not usable in meta-analysis

1 - The certainty of the evidence is based in the following judgments: Risk of bias: downgraded in one level since the overall risk of bias for studies was evaluated as 'high' and 'some concerns'; Inconsistency: downgraded in one level for inconsistency since the studies show contradictory results; Indirectness: no concerns; Imprecision: downgraded in one level for imprecision since each end of the confidence interval would lead to different conclusions; Publication bias: no concerns.

ty of the evidence is based in the following judgments: Risk of bias: downgraded in one level since the overall risk of bias for studies was evaluated as 'high' and 'some concerns' no concerns; Indirectness: no concerns; Imprecision: downgraded in two levels for imprecision since each end of the confidence interval would lead to widely different conclusions; as: no concerns.

3- The certainty of the evidence is based in the following judgments: Risk of bias: downgraded in one level since the overall risk of bias for studies was evaluated as 'high' and 'some concerns'; Inconsistency: no concerns; Indirectness: no concerns; Imprecision: no concerns; Publication bias: no concerns.

4- The certainty of the evidence cannot be estimated since the studies did not report this outcome. It is highly likely that the outcome was measured in the studies.

5- The certainty of the evidence is based in the following judgments: Risk of bias: downgraded in one level since the overall risk of bias for studies was evaluated as 'high' and 'some concerns'; Inconsistency: no concerns; Indirectness: no concerns; Imprecision: downgraded in one level for imprecision, since each end of the confidence interval would lead to different conclusions; Publication bias: no concerns.

7- The certainty of the evidence is based in the following judgments: Risk of bias: downgraded in one level since the overall risk of bias for studies was evaluated as 'high' and 'some concerns'; Inconsistency: no concerns; Indirectness: no concerns; Imprecision: no concerns; Publication bias: no concerns. 
medRxiv preprint doi: https://doi.org/10.1101/2020.09.27.20202754; this version posted September 28,2020 . The copyright holder for this preprint (which was not certified by peer review) is the author/funder, who has granted medRxiv a license to display the preprint in

It is made available under a CC-BY-NC-ND 4.0 International license .

\section{Introduction}

COVID-19 is an infection caused by the SARS-CoV-2 coronavirus [1]. It was first identified in Wuhan, China, on December 31, 2019 [2]; seven months later, more than fifteen million cases of contagion had been identified across 188 countries [3]. On March 11, 2020, WHO characterised the COVID-19 outbreak as a pandemic [1].

While the majority of cases result in mild symptoms, some might progress to pneumonia, acute respiratory distress syndrome and death $[4],[5],[6]$. The case fatality rate reported across countries, settings and age groups is highly variable, but it ranges from about $0.5 \%$ to $10 \%$ [7]. In hospitalised patients, it has been reported to be higher than $10 \%$ in some centres [8].

One of the strategies underway to identify effective interventions for COVID-19 is repurposing drugs that have been used for the treatment of other diseases.

Remdesivir is among these investigational medications. It is a directly acting antiviral agent, initially developed for the treatment of Ebola virus during the 2014 outbreak in Western Africa [9].

Remdesivir displays antiviral activity against many RNA viruses including SARS-CoV-2, in both in vitro [10] and animal studies [11].

Following the publication of the ACTT-1, a trial conducted by the National Institute of Allergy and Infectious Diseases (NIAID), the US Food and Drug Administration issued an emergency use authorisation of remdesivir for the treatment of COVID-19 [12].

However, the results of ACTT-1 were questioned immediately, particularly for the decision to stop it early for benefit [13]. On the other hand, the decision of the government of the United States of buying virtually all stocks of the drug, generated an urgent need of independent, transparent information about the effects of remdesivir for COVID-19.

Using innovative and agile processes, taking advantage of technological tools, and resorting to the collective effort of several research groups, this living systematic review aims to provide a timely, rigorous and continuously updated summary of the evidence available on the effects of remdesivir in patients with COVID-19 .

\section{Methods}

This manuscript complies with the 'Preferred Reporting Items for Systematic reviews and MetaAnalyses' (PRISMA) guidelines for reporting systematic reviews and meta-analyses [14] (see Appendix 1 - PRISMA Checklist).

A protocol stating the shared objectives and methodology of multiple evidence syntheses (systematic reviews and overviews of systematic reviews) to be conducted in parallel for different 
medRxiv preprint doi: https://doi.org/10.1101/2020.09.27.20202754; this version posted September 28, 2020. The copyright holder for this preprint (which was not certified by peer review) is the author/funder, who has granted medRxiv a license to display the preprint in It is made available under a CC-BY-NC-ND 4.0 International license .

103

104

105

106

107

108

109

questions relevant to COVID-19 was published elsewhere [15]. The review was registered in PROSPERO with the number CRD42020183384 and a full protocol was made available [16].

\section{Search strategies}

\section{Electronic searches}

We used the search strategies already developed in the L.OVE (Living OVerview of Evidence) platform (https://www.iloveevidence.com), a system that maps the evidence to different research questions. The full methods to maintain L.OVE are described in the website, but the process to devise the search strategies can be briefly described as:

- Identification of terms relevant to the population and intervention components of the search strategy, applying Word2vec technology [17] to the corpus of documents available in Epistemonikos Database.

- Discussion of terms with content and methods experts to identify relevant, irrelevant and missing terms.

- Creation of a sensitive boolean strategy encompassing all the relevant terms

- Iterative analysis of articles missed by the boolean strategy, and refinement of the strategy accordingly.

All the information in the L.OVE platform comes from a repository developed and maintained by Epistemonikos Foundation through the screening of different sources relevant to COVID-19. At the time of releasing this article, this repository included more than 66989 articles relevant to Coronavirus disease, coming from the following databases, trial registries, preprint servers and websites relevant to COVID-19: Epistemonikos database, Pubmed, EMBASE, ICTRP Search Portal, Clinicaltrials.gov, ISRCTN registry, Chinese Clinical Trial Registry, IRCT - Iranian Registry of Clinical Trials, EU Clinical Trials Register: Clinical trials for covid-19, NIPH Clinical Trials Search (Japan) - Japan Primary Registries Network (JPRN) (JapicCTI, JMACCT CTR, jRCT, UMIN CTR), UMIN-CTR - UMIN Clinical Trials Registry, JRCT - Japan Registry of Clinical Trials, JAPIC Clinical Trials Information, Clinical Research Information Service (CRiS), Republic of Korea, ANZCTR - Australian New Zealand Clinical Trials Registry, ReBec - Brazilian Clinical Trials Registry, CTRI - Clinical Trials Registry - India, DRKS German Clinical Trials Register, LBCTR - Lebanese Clinical Trials Registry, TCTR - Thai Clinical Trials Registry, NTR - The Netherlands National Trial Register,PACTR - Pan African Clinical Trial Registry, REPEC - Peruvian Clinical Trial Registry,SLCTR - Sri Lanka Clinical Trials Registry, medRxiv Preprints, bioRxiv Preprints, SSRN Preprints, WHO COVID-19 database. 
medRxiv preprint doi: https://doi.org/10.1101/2020.09.27.20202754; this version posted September 28,2020 . The copyright holder for this preprint (which was not certified by peer review) is the author/funder, who has granted medRxiv a license to display the preprint in

It is made available under a CC-BY-NC-ND 4.0 International license

137

138

139

140

141

142

143

144 The following strategy was used to retrieve from the repository the articles potentially eligible for 145

The last version of the methods, the total number of sources screened, and a living flow diagram and report of the project is updated regularly on the website [18].

The repository is continuously updated [18] and the information is transmitted in real time to the L.OVE platform, however, it was last checked for this review the day before release on 25 August 2020. The searches covered the period from the inception date of each database, and no study design, publication status or language restriction was applied. this review.

coronavir* OR coronovirus* OR betacoronavir* OR "beta-coronavirus" OR "beta-coronaviruses" OR "corona virus" OR "virus corona" OR "corono virus" OR "virus corono" OR hcov* OR covid* OR "2019-ncov" OR cv19* OR "cv-19" OR "cv 19" OR "n-cov" OR ncov* OR (wuhan* and (virus OR viruses OR viral)) OR sars* OR sari OR "severe acute respiratory syndrome" OR mers* OR "middle east respiratory syndrome" OR "middle-east respiratory syndrome" OR "2019-ncov-related" OR "cv19-related" OR "n-cov-related" AND (remdesivir* OR "GS-5734" OR "GS 5734" OR GS5734*)

\section{Other sources}

In order to identify articles that might have been missed in the electronic searches, we proceeded as follows:

- Screened the reference lists of other systematic reviews.

- Scanned the reference lists of selected guidelines, narrative reviews and other documents.

\section{Eligibility criteria}

We included randomised controlled trials evaluating patients infected with SARS-CoV-2 of any severity.

The intervention of interest was remdesivir at any dosage, duration, timing or route of administration. The comparison of interest was placebo (remdesivir plus standard of care versus placebo plus standard of care) or no treatment (remdesivir plus standard of care versus standard of care).

Our primary outcome of interest was all-cause mortality at longest follow-up. Secondary outcomes were invasive mechanical ventilation and adverse effects leading to discontinuation.

We also extracted information on the following outcomes: time to viral clearance, length of hospital stay and serious adverse effects. 
medRxiv preprint doi: https://doi.org/10.1101/2020.09.27.20202754; this version posted September 28,2020 . The copyright holder for this preprint (which was not certified by peer review) is the author/funder, who has granted medRxiv a license to display the preprint in

It is made available under a CC-BY-NC-ND 4.0 International license .

170 We did not consider the outcomes as an inclusion criteria during the selection process. Any article meeting all the criteria except for the outcome criterion was preliminarily included and assessed in full text.

173

\section{Selection of studies}

175 The results of the searches in the individual sources were de-duplicated by an algorithm that compares unique identifiers (database ID, DOI, trial registry ID), and citation details (i.e. author names, journal, year of publication, volume, number, pages, article title, and article abstract). Then, the information matching the search strategy was sent in real-time to the L.OVE platform where at least two authors independently screened the titles and abstracts yielded against the inclusion criteria. We obtained the full reports for all titles that appeared to meet the inclusion criteria or required further analysis and then decided about their inclusion.

182 We recorded the reasons for excluding trials in any stage of the search and outlined the study selection process in a PRISMA flow diagram which we adapted for the purpose of this project.

\section{Extraction and management of data}

Using standardised forms, two reviewers independently extracted the following data from each included trial: study design, setting, participant characteristics (including disease severity and age) and study eligibility criteria; details about the administered intervention and comparison, including dose, duration and timing (i.e. time after diagnosis); the outcomes assessed and the time they were measured; the source of funding of the study and the conflicts of interest disclosed by the investigators; the risk of bias assessment for each individual study. We resolved disagreements by discussion, with one arbiter adjudicating unresolved disagreements.

\section{Risk of bias assessment}

The risk of bias for each randomised trial was assessed by using the 'risk of bias' tool (RoB 2.0: a revised tool to assess risk of bias in randomised trials) [19], considering the following domains of bias for each outcome result of all reported outcomes and time points: bias due to (1) the randomisation process, (2) deviations from intended interventions (effects of assignment to interventions at baseline), (3) missing outcome data, (4) measurement of the outcome, and (5) selection of reported results.

201 Discrepancies between review authors were resolved by discussion to reach consensus. If necessary, a third review author was consulted to achieve a decision. 
medRxiv preprint doi: https://doi.org/10.1101/2020.09.27.20202754; this version posted September 28, 2020. The copyright holder for this preprint (which was not certified by peer review) is the author/funder, who has granted medRxiv a license to display the preprint in

It is made available under a CC-BY-NC-ND 4.0 International license .

204

205

206

207

208

209

210

211

212

\section{Measures of treatment effect}

For dichotomous outcomes, we expressed the estimate of treatment effect of an intervention as risk ratios (RR) along with $95 \%$ confidence intervals $(\mathrm{Cl})$.

For continuous outcomes, we used the mean difference and standard deviation to summarise the data along with $95 \% \mathrm{Cl}$. For continuous outcomes reported using different scales, the treatment effect was expressed as a standardised mean difference with $95 \% \mathrm{Cl}$.

\section{Strategy for data synthesis}

The results of the search and the selection of the studies is presented, by means of the corresponding flow chart, according to recommendations of the PRISMA statement [14]. For any outcomes where it was not possible to calculate an effect estimate, a narrative synthesis is presented, describing the studies in terms of the direction and the size of effects, and any available measure of precision

For any outcomes where data was available from more than one trial, we conducted a formal quantitative synthesis (meta-analysis) for studies clinically homogeneous using RevMan 5 [20], using the inverse variance method with the random-effects model. We assessed inconsistency by visual inspection of the forest plots and using the $\mathrm{I}^{2}$ index.

\section{Subgroup and sensitivity analysis}

As few trials were found, we did not perform sensitivity or subgroup analysis.

Assessment of certainty of evidence

The certainty of the evidence for all outcomes was judged using the Grading of Recommendations Assessment, Development and Evaluation working group methodology (GRADE Working Group) [21], across the domains of risk of bias, consistency, directness, precision and reporting bias. For the main comparisons and outcomes, we prepared a Summary of Findings (SoF) tables [22],[23].

\section{Living evidence synthesis}

An artificial intelligence algorithm deployed in the Coronavirus/COVID-19 topic of the L-OVE platform provides instant notification of articles with a high likelihood of being eligible. The authors review them, decide upon inclusion, and update the living web version of the review accordingly.

This review is part of a larger project set up to produce multiple parallel systematic reviews relevant to COVID-19 [15]. 
medRxiv preprint doi: https://doi.org/10.1101/2020.09.27.20202754; this version posted September 28, 2020. The copyright holder for this preprint (which was not certified by peer review) is the author/funder, who has granted medRxiv a license to display the preprint in It is made available under a CC-BY-NC-ND 4.0 International license.

\section{Results}

239

\section{Results of the search}

241 We conducted searches using L·OVE (Living OVerview of Evidence) platform for COVID-19, a system

242 that maps PICO questions to a repository, maintained through regular searches in 27 databases,

243 preprint servers, trial registries and websites relevant to COVID-19. All the searches covered the

244 period until 25 August 2020. No date or language restrictions were applied.

245 The search in the L.OVE platform yielded 574 records after removal of duplicates. We considered

246489 as potentially eligible and obtained and evaluated their full texts. We finally included 3

247 randomised trials (11 references) [24],[25], [26].

248 The reasons for excluding studies at the time of full-text review were the following: not a primary

249 study in humans (396 records); wrong study design (51 records) and wrong comparison (3 records).

250 We also identified 16 ongoing randomised trials.

252 The complete study selection process is summarised in the PRISMA flow chart (Figure 1) and the full 253 list of included, excluded and ongoing trials is presented in Appendix 2.

255 Figure 1 - PRISMA Flowchart (prepared by the authors from the study data). 
medRxiv preprint doi: https://doi.org/10.1101/2020.09.27.20202754; this version posted September 28, 2020. The copyright holder for this preprint (which was not certified by peer review) is the author/funder, who has granted medRxiv a license to display the preprint in It is made available under a CC-BY-NC-ND 4.0 International license

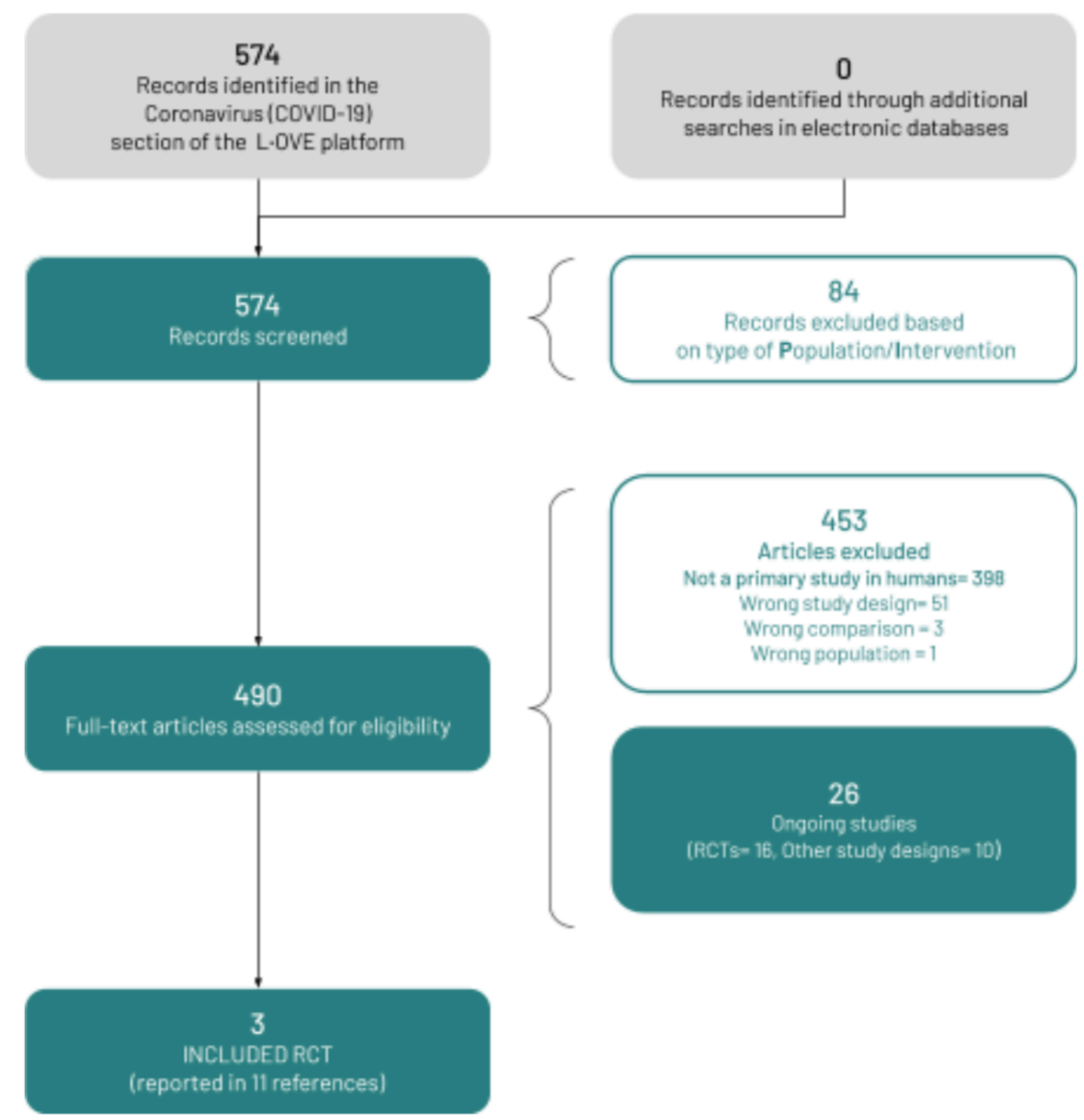

\section{Description of the included studies}

The three trials identified were the Adaptive COVID-19 Treatment Trial (ACTT-1 [24]), the CAP-China remdesivir 2 [25] and SIMPLE 2 [26]. All trials evaluated inpatient adults. ACTT-1 required for inclusion that one of the following criteria were also fulfilled: $\mathrm{SpO} 2</=94 \%$ on room air, requiring supplemental oxygen, requiring mechanical ventilation or radiographic infiltrates by any imaging test. CAP-China remdesivir 2 required that patients had an oxygen saturation of $94 \%$ or lower on room air or a ratio of arterial oxygen partial pressure to fractional inspired oxygen of $300 \mathrm{~mm} \mathrm{Hg}$ or less. Additionally, patients in CAP-China remdesivir 2 had to present within 12 days of symptom onset. SIMPLE 2 [26] required that patients had any radiographic evidence of pulmonary infiltrates and oxygen saturation $>94 \%$ on room air Table 1 and 2 summarises inclusion criteria of the trials and characteristics of the intervention. More details are presented in Appendix 2. Table 1 presents the complete inclusion criteria of the trials. 
medRxiv preprint doi: https://doi.org/10.1101/2020.09.27.20202754; this version posted September 28, 2020. The copyright holder for this preprint (which was not certified by peer review) is the author/funder, who has granted medRxiv a license to display the preprint in

It is made available under a CC-BY-NC-ND 4.0 International license .

Table 1 - Inclusion criteria of the studies

\begin{tabular}{|c|c|c|c|c|c|}
\hline & Age & Setting & $\begin{array}{l}\text { Confirmation } \\
\text { method }\end{array}$ & $\begin{array}{l}\text { Clinical or severity } \\
\text { parameters }\end{array}$ & $\begin{array}{l}\text { Radiological findings as } \\
\text { criteria }\end{array}$ \\
\hline ACTT-1 [24] & Adults & Hospital & RT-PCR & $\begin{array}{l}\text { One of several criteria (SpO2 } \\
</=94 \% \text { on room air, OR } \\
\text { Requiring supplemental } \\
\text { oxygen, OR Requiring } \\
\text { mechanical ventilation.) }\end{array}$ & $\begin{array}{l}\text { One of several criteria } \\
\text { (radiographic infiltrates } \\
\text { by any imaging test) }\end{array}$ \\
\hline $\begin{array}{l}\text { CAP-China } \\
\text { remdesivir } \\
2[25]\end{array}$ & Adults & Hospital & RT-PCR & $\begin{array}{l}\text { Mandatory (Oxygen } \\
\text { saturation of } 94 \% \text { or lower on } \\
\text { room air or a ratio of arterial } \\
\text { oxygen partial pressure to } \\
\text { fractional inspired oxygen of } \\
300 \mathrm{~mm} \mathrm{Hg} \text { or less, and were } \\
\text { within } 12 \text { days of symptom } \\
\text { onset) }\end{array}$ & $\begin{array}{l}\text { Mandatory } \text { (pneumonia } \\
\text { confirmed by chest } \\
\text { imaging) }\end{array}$ \\
\hline $\begin{array}{ll}\text { SIMPLE } & 2 \\
{[26]} & \end{array}$ & $\begin{array}{l}\text { Adults and } \\
\text { children }\end{array}$ & Hospital & RT-PCR & $\begin{array}{l}\text { Mandatory ( } \mathrm{SpO} 2>94 \% \text { on } \\
\text { room air at screening) }\end{array}$ & $\begin{array}{l}\text { Mandatory (any } \\
\text { radiographic evidence of } \\
\text { pulmonary infiltrates) }\end{array}$ \\
\hline
\end{tabular}

All trials administered the same doses of remdesivir plus standard care [24] , [25], [26]. One trial included two intervention arms of remdesivir (5-day and 10-day course of remdesivir) [26]. None of the trials provide further details regarding the standard care treatment delivered. Two trials reported that the standard of care was determined by the trial site hospital [24] The other one, only reported that concomitant use of lopinavir/ritonavir, interferons, and corticoids were permitted [25].

Table 2 - Characteristics of the intervention

\begin{tabular}{|c|c|c|c|c|}
\hline & $\begin{array}{l}\text { Interventio } \\
n\end{array}$ & Dose & Duration & Standard care \\
\hline $\begin{array}{l}\text { ACTT-1 } \\
{[24]}\end{array}$ & Remdesivir & $\begin{array}{l}200 \mathrm{mg} \text { in } \\
\text { day } 1 \text {, } \\
\text { followed } \\
\text { by } 100 \\
\text { mg qd }\end{array}$ & 10 days & $\begin{array}{l}\text { All patients received supportive care according to the standard of } \\
\text { care for the trial site hospital. If a hospital had a written policy or } \\
\text { guideline for use of other treatments for Covid-19, patients could } \\
\text { receive those treatments. In the absence of a written policy or } \\
\text { guideline, other experimental treatment or off-label use of } \\
\text { marketed medications intended as specific treatment for Covid-19 } \\
\text { were prohibited from day } 1 \text { through day } 29 \text { (though such } \\
\text { medications could have been used before enrollment in this trial). }\end{array}$ \\
\hline $\begin{array}{l}\text { CAP-China } \\
\text { remdesivir } \\
2[25]\end{array}$ & Remdesivir & $\begin{array}{l}200 \mathrm{mg} \text { in } \\
\text { day } 1 \text {, } \\
\text { followed } \\
\text { by } 100 \\
\text { mg qd }\end{array}$ & 10 days & $\begin{array}{l}\text { No standard treatment was reported. Patients were permitted } \\
\text { concomitant use of lopinavir-ritonavir, interferons, and } \\
\text { corticosteroids }\end{array}$ \\
\hline $\begin{array}{ll}\text { SIMPLE } & 2 \\
{[26]} & \end{array}$ & Remdesivir & $\begin{array}{l}200 \mathrm{mg} \text { in } \\
\text { day } 1 \text {, } \\
\text { followed } \\
\text { by } 100 \\
\text { mg qd }\end{array}$ & $5 / 10$ days & $\begin{array}{l}\text { Treatment with standard of care according to local guidelines. The } \\
\text { original protocol allowed use of other agents with presumptive } \\
\text { activity against SARS-CoV-2 if such use was local standard care. } \\
\text { This exception was disallowed in a subsequent amendment. }\end{array}$ \\
\hline
\end{tabular}


medRxiv preprint doi: https://doi.org/10.1101/2020.09.27.20202754; this version posted September 28 , 2020. The copyright holder for this preprint (which was not certified by peer review) is the author/funder, who has granted medRxiv a license to display the preprint in It is made available under a CC-BY-NC-ND 4.0 International license

283 In total, trials included 1896 hospitalized patients [24], [25], [26]. One trial was conducted in China 284 [25] and the other two were multicenters trials conducted in several countries [24] [26]. All trials 285 included patients with radiologically confirmed pneumonia [25], [25], [26]. Baseline characteristics of participants regarding age, gender, and chronic disease were similar between studies, but the number of patients requiring supplemental oxygen or mechanical ventilation varied substantially between trials [24], [25].

Table 3 - Baseline characteristics of the participants

\begin{tabular}{|c|c|c|c|}
\hline & ACTT-1 [24] & $\begin{array}{l}\text { CAP-China remdesivir } 2 \\
\text { [25] }\end{array}$ & SIMPLE 2 [26] \\
\hline Number randomised & 1063 & 237 & 596 \\
\hline $\begin{array}{l}\text { Geographic location } \\
\text { and Setting }\end{array}$ & $\begin{array}{l}\text { United States,Europe and } \\
\text { Asia; inpatient setting }\end{array}$ & China;inpatient setting & $\begin{array}{l}\text { United States,Europe and } \\
\text { Asia;inpatient setting }\end{array}$ \\
\hline Mean age (years) & 58.9 & 65 & 57 \\
\hline Females (\%) & 35.7 & 41 & 38.8 \\
\hline $\begin{array}{l}\text { Time from } \\
\begin{array}{l}\text { onset to treatment } \\
\text { (days) }\end{array}\end{array}$ & 9 & 10 & 9 \\
\hline Pneumonia (\%) & 100 & 100 & 100 \\
\hline $\begin{array}{l}\text { Supplemental oxygen } \\
\text { or NIRS (\%) }\end{array}$ & 39.6 & 83 & 15.1 \\
\hline $\begin{array}{l}\text { Receiving } \\
\text { mechanical ventilation } \\
\text { (\%) }\end{array}$ & 25.6 & 0.3 & Not reported \\
\hline $\begin{array}{l}\text { Underlying chronic } \\
\text { diseases } \\
\text { (\%) }\end{array}$ & $\begin{array}{l}49.6 \% \text { hypertension, } 37 \% \\
\text { obesity, } 29.7 \% \text { diabetes }\end{array}$ & $\begin{array}{l}\text { Hypertension: } 72(46 \%) \text { vs } \\
30(38 \%) ; \text { Diabetes:40 (25\%) } \\
\text { vs } 16(21 \%) \text {; Coronary heart } \\
\text { disease: } 15(9 \%) \text { vs } 2(3 \%)\end{array}$ & $\begin{array}{l}\text { Cardiovascular disease: } \\
56 \% \text {, hypertension: } 42 \% \text {, } \\
\text { Diabetes } 40 \% \text {, Asthma: } 14 \%\end{array}$ \\
\hline
\end{tabular}

\section{Risk of bias in the included studies}

We judge that the overall risk of bias was "high" for all outcomes regarding the ACTT-1 trial [24]. The study was judged to raise "some concerns" in deviations from the intended intervention domain and 
medRxiv preprint doi: https://doi.org/10.1101/2020.09.27.20202754; this version posted September 28, 2020. The copyright holder for this preprint (which was not certified by peer review) is the author/funder, who has granted medRxiv a license to display the preprint in

It is made available under a CC-BY-NC-ND 4.0 International license

"some concern" for all outcomes, because of problems in the randomization process [25]. SIMPLE 2 overall risk of bias was some concern for all outcomes due to deviations from intended interventions [26]. Table 4 summarises the risk of bias assessments and details of each assessment are presented in Appendix 2.

Table 4 summarises the risk of bias assessments and details of each assessment are presented in Appendix 2.

Table 4- Risk of bias in the included studies assessed by ROB-2 tool

\begin{tabular}{|c|c|c|c|c|c|c|}
\hline & $\begin{array}{l}\text { Risk of bias } \\
\text { arising from } \\
\text { the } \\
\text { randomisati } \\
\text { on process }\end{array}$ & \begin{tabular}{|lr} 
Risk of bias \\
due to \\
deviations \\
from the \\
intended \\
intervention
\end{tabular} & $\begin{array}{lr}\text { Risk of bias } \\
\text { due } & \text { to } \\
\text { missing } & \\
\text { outcome data }\end{array}$ & $\begin{array}{l}\text { Risk of bias in } \\
\text { the } \\
\text { measurement } \\
\text { of the } \\
\text { outcome }\end{array}$ & $\begin{array}{l}\text { Risk of bias in } \\
\text { the selection } \\
\text { of } \quad \text { the } \\
\text { reported } \\
\text { result }\end{array}$ & $\begin{array}{l}\text { Overall risk of } \\
\text { bias }\end{array}$ \\
\hline ACTT-1 [24] & Low & Some concerns & High & Low & Low & High \\
\hline $\begin{array}{l}\text { CAP-China } \\
\text { remdesivir } 2 \\
{[25]}\end{array}$ & $\begin{array}{l}\text { Some } \\
\text { concerns }\end{array}$ & Low & Low & Low & Low & Some concerns \\
\hline SIMPLE 2 [26] & Low & Some concerns & Low & Low & Low & Some concerns \\
\hline
\end{tabular}

\section{Efficacy of remdesivir in the treatment of patients with COVID-19}

307 The main results are summarised in the Summary of Findings table, presented at the beginning of

the manuscript.

\section{Primary outcome}

311 All-cause mortality.

312 All studies reported this outcome [24],[25],[26] and the evidence is very uncertain about the effect of remdesivir on mortality (RR $0.7,95 \% \mathrm{Cl} 0.46$ to 1.05 ; very low certainty evidence).

Figure 2 - Relative risk for all-cause mortality for remdesivir versus standard care (prepared by the authors from the study data).

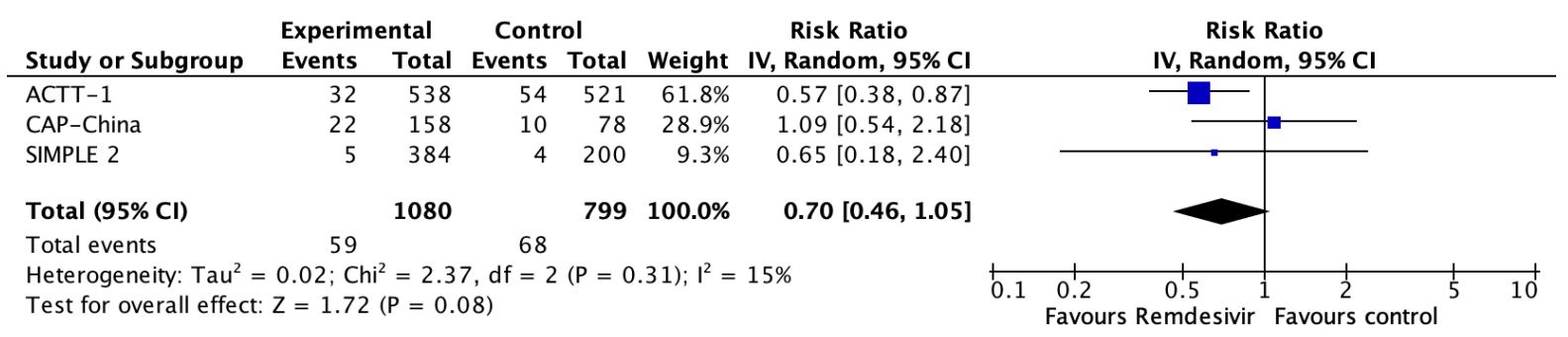


medRxiv preprint doi: https://doi.org/10.1101/2020.09.27.20202754; this version posted September 28 , 2020. The copyright holder for this preprint (which was not certified by peer review) is the author/funder, who has granted medRxiv a license to display the preprint in

It is made available under a CC-BY-NC-ND 4.0 International license .

318

319

320

321

322

323

324

325

326

327

328

329

330

331

332

333

\section{Secondary outcomes}

\section{Invasive mechanical ventilation}

All studies reported this outcome [24],[25],[26] and the evidence is very uncertain about the effect of remdesivir on the need for invasive mechanical ventilation (RR $0.69,95 \% \mathrm{Cl} 0.39$ to 1.24 ; very low certainty evidence).

Figure 3 - Relative risk for invasive mechanical ventilation for remdesivir versus standard care (prepared by the authors from the study data).

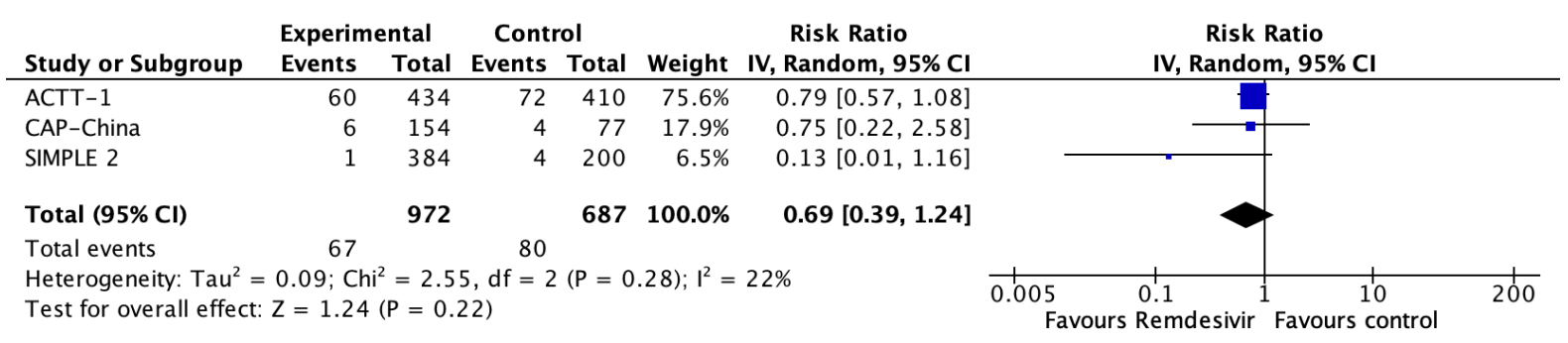

\section{Adverse effects leading to discontinuation}

Two trials reported this outcome [24],[25] and remdesivir likely results in a large reduction in the incidence of adverse effects (RR 1.29, $95 \% \mathrm{Cl} 0.58$ to 2.84 ; moderate certainty evidence).

Figure 4 - Relative risk for adverse effects leading to discontinuation for remdesivir versus standard care (prepared by the authors from the study data).

\begin{tabular}{|c|c|c|c|c|c|c|c|c|}
\hline Study or Subgroup & \multicolumn{2}{|c|}{ Experimental } & \multicolumn{2}{|c|}{ Control } & Weight & $\begin{array}{c}\text { Risk Ratio } \\
\text { IV, Random, } 95 \% \mathrm{Cl}\end{array}$ & \multicolumn{2}{|l|}{$\begin{array}{c}\text { Risk Ratio } \\
\text { IV, Random, 95\% Cl }\end{array}$} \\
\hline ACTT-1 & 36 & 541 & 36 & 522 & $66.1 \%$ & $0.96[0.62,1.51]$ & & \\
\hline CAP-China & 18 & 155 & 4 & 78 & $33.9 \%$ & $2.26[0.79,6.46]$ & & \\
\hline Total $(95 \% \mathrm{CI})$ & & 696 & & 600 & $100.0 \%$ & $1.29[0.58,2.84]$ & & \\
\hline Total events & 54 & & 40 & & & & & \\
\hline $\begin{array}{l}\text { Heterogeneity: } \mathrm{Tau}^{2}= \\
\text { Test for overall effect }\end{array}$ & $\begin{array}{l}0.19 ; C h \\
Z=0.63\end{array}$ & $\begin{array}{l}=2.1 \\
=0.5\end{array}$ & $\begin{array}{l}\text { 5, } \mathrm{df}=1 \\
\text { 53) }\end{array}$ & $(P=$ & 4); $1^{2}$ & $54 \%$ & $\begin{array}{lll}0.01 & 0.1 & 1\end{array}$ & 10 \\
\hline
\end{tabular}

\section{Time to viral clearance}

This outcome was not measured or reported by the included studies

\section{Length of hospital stay}

Two studies reported this outcome [25],[26], but only one was usable for meta analysis [25]. SIMPLE 2 trial reported that there were no significant differences between the remdesivir and standard care groups in duration of hospitalisation [25]. Quantitative synthesis showed remdesivir may result in little to no difference in the duration of hospitalisation (MD 1, 95\% Cl -2.86 to 4.86; Low certainty evidence). 
medRxiv preprint doi: https://doi.org/10.1101/2020.09.27.20202754; this version posted September 28 , 2020. The copyright holder for this preprint (which was not certified by peer review) is the author/funder, who has granted medRxiv a license to display the preprint in

It is made available under a CC-BY-NC-ND 4.0 International license.

Figure 5 - Relative risk for length of hospital stay for remdesivir versus standard care (prepared by the authors from the study data).

\begin{tabular}{|c|c|c|c|c|c|c|c|c|c|}
\hline \multirow[b]{2}{*}{ Study or Subgroup } & \multicolumn{3}{|c|}{ Experimental } & \multicolumn{3}{|c|}{ Control } & \multicolumn{2}{|r|}{ Mean Difference } & \multirow{2}{*}{$\begin{array}{l}\text { Mean Difference } \\
\text { IV, Random, 95\% CI }\end{array}$} \\
\hline & Mean & SD & Total & Mean & SD & Total & Weight & IV, Random, 95\% CI & \\
\hline CAP-China & 25 & 16 & 158 & 24 & 14 & 78 & $100.0 \%$ & $1.00[-2.98,4.98]$ & \\
\hline Total $(95 \% \mathrm{Cl})$ & & & 158 & & & 78 & $100.0 \%$ & $1.00[-2.98,4.98]$ & \\
\hline $\begin{array}{l}\text { Heterogeneity: Not al } \\
\text { Test for overall effect }\end{array}$ & $\begin{array}{l}\text { plicable } \\
Z=0.4\end{array}$ & $(P$ & $0.62)$ & & & & & & $\begin{array}{ccccc}1 & 1 & 1 & 1 & \\
-4 & -2 & 0 & 2 & 4 \\
\text { Remdesivir } & \text { Favours col }\end{array}$ \\
\hline
\end{tabular}

\section{Serious adverse effects}

349 All studies reported this outcome [24],[25],[26] and remdesivir likely reduces the number of serious adverse effects ( $R R 0.74,95 \% \mathrm{Cl} 0.62$ to 0.9 ; moderate certainty evidence).

Figure 6 - Relative risk for serious adverse effects for remdesivir versus standard care (prepared by the authors from the study data).

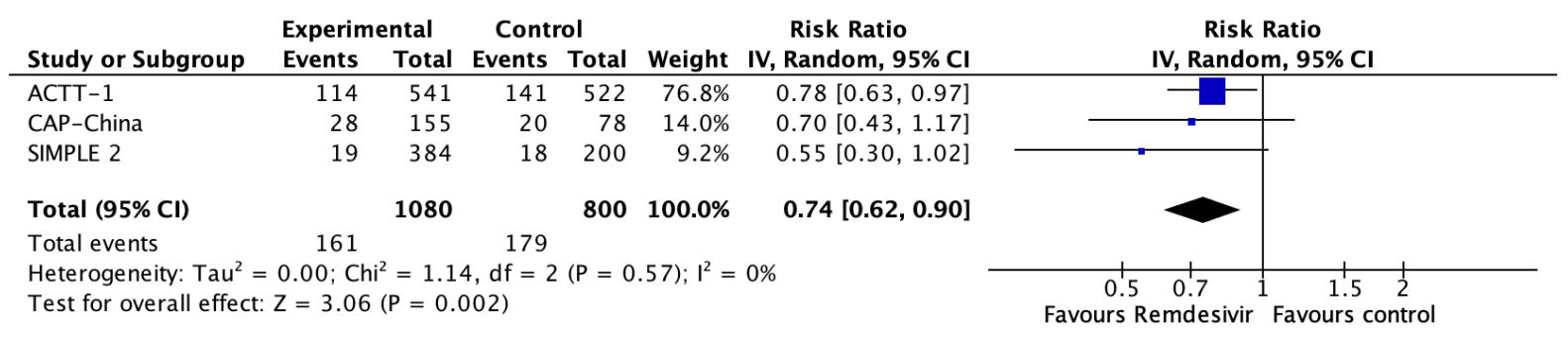

\section{Discussion}

356 We conducted a systematic review and identified 3 randomised trials that reported data on the effect of remdesivir in patients with COVID-19 [24],[25],[26]. Even though remdesivir appears to be safe, the evidence is very uncertain about the impact on the outcomes critical for decision-making in moderate and severe patients, the more relevant clinical scenario for this drug, such as mortality and need of mechanical ventilation.

It is unfortunate not knowing yet if one of the pharmaceutical interventions that has sparked more interest is effective or not. One of the limitations comes from the lack of precision of the result for the main outcomes. The early termination of the ACTT-1 trial can be seen as a missed opportunity in this regard [25].

In addition, all the trials concluded enrollment before the release of the RECOVERY trial which showed a mortality reduction with dexamethasone [27]. It is not clear if this factor would modify the effect, if any, of remdesivir. By now, clinicians and other decision makers are in a difficult position. The pressure to act is high, particularly after the the US Food and Drug Administration issued an emergency use authorisation of remdesivir for the treatment of COVID-19 [12]. We anticipate that the range of recommendations 
medRxiv preprint doi: https://doi.org/10.1101/2020.09.27.20202754; this version posted September 28,2020 . The copyright holder for this preprint (which was not certified by peer review) is the author/funder, who has granted medRxiv a license to display the preprint in

It is made available under a CC-BY-NC-ND 4.0 International license .

371 from different organisations should range between a suggestion against its use and a weak recommendation for its use in severe cases, especially in settings without resource constraints.

373

374 There are at least 46 ongoing trials that we expect will provide data in the near future. Making sense of this information is not going to be an easy task. Systematic reviews are considered the gold standard to make sense of multiple trials addressing a similar scientific question, but the traditional model for conducting reviews has several limitations, including a high demand for time and resources [28] and a rapid obsolescence [29]. Amidst the COVID-19 crisis, researchers should make their best effort to answer the urgent needs of health decision makers yet without giving up scientific accuracy. Information is being produced at a vertiginous speed [30], so alternative models are needed.

382

One potential solution to these shortfalls are rapid reviews, a form of knowledge synthesis that streamlines or omits specific methods of a traditional systematic review in order to move faster. Unfortunately, in many cases, this rapidity comes at the cost of quality [31]. Furthermore, they do not solve the issue of obsolescence. Living systematic reviews do address that issue [32]. They are continually updated by incorporating relevant new evidence as it becomes available, at a substantial effort. So, an approach combining these two models might prove more successful in providing the scientific community and other interested parties with evidence that is actionable, rapidly and efficiently produced, up to date, and of the highest quality [33].

This review is part of a larger project set up to put such an approach into practice. The project aims to produce multiple parallel living systematic reviews relevant to COVID-19 following the higher standards of quality in evidence synthesis production [15]. We believe that our methods are well suited to handle the abundance of evidence that is to come, including evidence on the role of lopinavir/ritonavir for COVID-19.

During the COVID-19 pandemic, we will maintain the search and selection of evidence for this review continuously updated, and we will every time the conclusions change or whenever there are substantial updates. Our systematic review aims to provide high-quality, up-to-date synthesis of the evidence that is useful for clinicians and other decision-makers. 
medRxiv preprint doi: https://doi.org/10.1101/2020.09.27.20202754; this version posted September 28 , 2020. The copyright holder for this preprint (which was not certified by peer review) is the author/funder, who has granted medRxiv a license to display the preprint in

It is made available under a CC-BY-NC-ND 4.0 International license .

405 The members of the COVID-19 L.OVE Working Group and Epistemonikos Foundation have made 406 possible to build the systems and compile the information needed by this project. Epistemonikos is a 407 collaborative effort, based on the ongoing volunteer work of over a thousand contributors since 4082012.

409

410 Roles and contributions

411 All the review authors drafted and revised the protocol, conducted article screening and data 412 collection, and drafted and revised the review.

413 The COVID-19 L.OVE Working Group was created by Epistemonikos and a number of expert teams in 414 order to provide decision makers with the best evidence related to COVID-19. Up-to-date 415 information about the group and its member organisations is available here: 416 epistemonikos.cl/working-group

417

418 Competing interests

419 All authors declare no financial relationships with any organisation that might have a real or 420 perceived interest in this work. There are no other relationships or activities that might have 421 influenced the submitted work.

422

423 Funding

424 This project was not commissioned by any organisation and did not receive external funding.

425 Epistemonikos Foundation is providing training, support and tools at no cost for all the members of 426 the COVID-19 L.OVE Working Group.

427

\section{PROSPERO registration number}

CRD42020183384

430

Ethics

432 As researchers will not access information that could lead to the identification of an individual 433 participant, obtaining ethical approval was waived.

434

\section{Data sharing}

436 All data related to the project will be available. Epistemonikos Foundation will grant access to data. 
medRxiv preprint doi: https://doi.org/10.1101/2020.09.27.20202754; this version posted September 28, 2020. The copyright holder for this preprint (which was not certified by peer review) is the author/funder, who has granted medRxiv a license to display the preprint in It is made available under a CC-BY-NC-ND 4.0 International license .

1. World Health Organization. Director-General's remarks at the media briefing on 2019-nCoV on 11 February 2020. [Internet] World Health Organization; 2020 [Accessed 2020 April 12] Available from: https://www.who.int/dg/speeches/detail/who-director-general-s-remarksat-the-media-briefing-on-2019-ncov-on-11-february-2020 .

2. Hui DS, I Azhar E, Madani TA, et al. The continuing 2019-nCoV epidemic threat of novel coronaviruses to global health - The latest 2019 novel coronavirus outbreak in Wuhan, China. Int J Infect Dis. 2020 Feb;91:264-266. Available from: doi:10.1016/j.ijid.2020.01.009

3. Dong E, Du H, Gardner L. An interactive web-based dashboard to track COVID-19 in real time. Lancet Infect Dis. 2020 Feb 19

4. Guan WJ, Ni ZY, Hu Y, et al. Clinical Characteristics of Coronavirus Disease 2019 in China. N Engl J Med 2020. Available from: doi:10.1056/NEJMoa2002032

5. Tavakoli A, Vahdat K, Keshavarz M. Novel Coronavirus Disease 2019 (COVID-19): An Emerging Infectious Disease in the 21st Century. BPUMS. 2020;22(6):432-450. Available from: doi:10.29252/ismj.22.6.432

6. Li LQ, Huang T, Wang YQ, Wang ZP, Liang Y, Huang TB, et al. 2019 novel coronavirus patients' clinical characteristics, discharge rate and fatality rate of meta-analysis. Journal of medical virology. 2020. Available from: doi:10.1002/jmv.25757

7. Global Covid-19 Case Fatality Rates [Internet] UK: Centre for Evidence-Based Medicine [Accessed 2020 April 12]. Available from: https://www.cebm.net/covid-19/global-covid-19case-fatality-rates/

8. Rodriguez-Morales AJ, Cardona-Ospina JA, Gutiérrez-Ocampo E, et al. Clinical, laboratory and imaging features of COVID-19: A systematic review and meta-analysis. Travel medicine and infectious disease. 2020;101623. Available from: doi:10.1016/j.tmaid.2020.101623

9. Siegel D, Hui HC, Doerffler E, Clarke MO, Chun K, Zhang L, Neville S, Carra E, Lew W, Ross B, Wang Q, Wolfe L, Jordan R, Soloveva V, Knox J, Perry J, Perron M, Stray KM, Barauskas O, Feng JY, Xu Y, Lee G, Rheingold AL, Ray AS, Bannister R, Strickley R, Swaminathan S, Lee WA, Bavari S, Cihlar T, Lo MK, Warren TK, Mackman RL. Discovery and Synthesis of a Phosphoramidate Prodrug of a Pyrrolo[2,1-f][triazin-4-amino] Adenine C-Nucleoside (GS5734) for the Treatment of Ebola and Emerging Viruses. Journal of medicinal chemistry. 2017;60(5):1648-1661

10. Sheahan TP, Sims AC, Graham RL, Menachery VD, Gralinski LE, Case JB, Leist SR, Pyrc K, Feng JY, Trantcheva I, Bannister R, Park Y, Babusis D, Clarke MO, Mackman RL, Spahn JE, Palmiotti CA, Siegel D, Ray AS, Cihlar T, Jordan R, Denison MR, Baric RS. Broad-spectrum antiviral GS- 
medRxiv preprint doi: https://doi.org/10.1101/2020.09.27.20202754; this version posted September 28, 2020. The copyright holder for this preprint (which was not certified by peer review) is the author/funder, who has granted medRxiv a license to display the preprint in It is made available under a CC-BY-NC-ND 4.0 International license .

5734 inhibits both epidemic and zoonotic coronaviruses. Science translational medicine. 2017;9(396).

11. Brandi Williamson, Friederike Feldmann, Benjamin Schwarz, Kimberly Meade-White, Danielle Porter, Jonathan Schulz, Neeltje van Doremalen, Ian Leighton, Claude Kwe Yinda, Lizzette Perez-Perez, Atsushi Okumura, Jamie Lovaglio, Patrick Hanley, Greg Saturday, Catharine Bosio, Sarah Anzick, Kent Barbian, Tomas Chilar, Craig Martens, Dana Scott, Vincent Munster, Emmie de Wit. Clinical benefit of remdesivir in rhesus macaques infected with SARS-CoV-2. bioRxiv. 2020

12. U.S. Food and Drug Administration. Coronavirus (COVID-19) Update: FDA Issues Emergency Use Authorization for Potential COVID-19 Treatment. FDA NEWS RELEASE. 2020;

13. Herper M. Inside the NIH's controversial decision to stop its big remdesivir study. STAT. 2020

14. Moher D, Liberati A, Tetzlaff J, Altman DG; PRISMA Group. Preferred reporting items for systematic reviews and meta-analyses: the PRISMA statement. J Clin Epidemiol. 2009;62(10):1006-1012. doi:10.1016/j.jclinepi.2009.06.005

15. Rada G, Verdugo-Paiva F, Ávila C, Morel-Marambio M, Bravo-Jeria R, Pesce F, et al; COVID-19 L.OVE Working Group. Evidence synthesis relevant to COVID-19: a protocol for multiple systematic reviews and overviews of systematic reviews. Medwave 2020;20(3):e7867. Available from: doi:10.5867/medwave.2020.03.7867

16. Verdugo F, Acuña MP, Solà I, Rada G. Remdesivir for the treatment of COVID-19: A living systematic review protocol. OSF 2020. Available from: doi:10.31219/osf.io/zwqf2

17. Github repository [Internet] [Accessed 2020 April 3 Available from: https://github.com/dperezrada/keywords2vec

18. Methods for the special L.OVE of Coronavirus infection [Internet] Santiago: Epistemonikos Foundation [Accessed 2020 April 3]. Available from: https://app.iloveevidence.com/covid-19

19. Sterne JAC, Savović J, Page MJ, Elbers RG, Blencowe NS, Boutron I, et al. RoB 2: a revised tool for assessing risk of bias in randomised trials. BMJ. 2019 Aug 28;366:14898. Available from: doi:10.1136/bmj.14898

20. Review Manager (RevMan) [Software]. Version 5.3.5 Copenhagen: The Nordic Cochrane Centre, The Cochrane Collaboration, 2014.

21. Guyatt GH, Oxman AD, Vist GE, Kunz R, Falck-Ytter Y, Alonso-Coello P, et al; GRADE Working Group. GRADE: an emerging consensus on rating quality of evidence and strength of recommendations. BMJ. 2008 Apr 26;336(7650):924-6. Available from: doi:10.1136/bmj.39489.470347.AD Available from: doi:10.1016/j.jclinepi.2012.01.012 
medRxiv preprint doi: https://doi.org/10.1101/2020.09.27.20202754; this version posted September 28, 2020. The copyright holder for this preprint (which was not certified by peer review) is the author/funder, who has granted medRxiv a license to display the preprint in It is made available under a CC-BY-NC-ND 4.0 International license .

505

506

507

508

509

510

511

512

513

514

515

516

517

518

519

520

521

522

523

524

525

526

527

528

529

530

531

532

533

534

535

536

537

22. Guyatt GH, Oxman AD, Santesso N, et al. GRADE guidelines: 12. Preparing summary of findings tables-binary outcomes. J Clin Epidemiol [Internet] 2013 Feb [Accessed March 26] ;66(2):158-72. Available from: doi:10.1016/j.jclinepi.2012.01.012

23. Guyatt GH, Thorlund K, Oxman AD, et al. GRADE guidelines: 13. Preparing summary of findings tables and evidence profiles-continuous outcomes. J Clin Epidemiol 2013 Feb;66(2):173-83. Available from: doi:10.1016/j.jclinepi.2012.08.001

24. Beigel JH, Tomashek KM, Dodd LE, Mehta AK, Zingman BS, Kalil AC, Hohmann E, Chu HY, Luetkemeyer A, Kline S, Lopez de Castilla D, Finberg RW, Dierberg K, Tapson V, Hsieh L, Patterson TF, Paredes R, Sweeney DA, Short WR, Touloumi G, Lye DC, Ohmagari N, Oh MD, Ruiz-Palacios GM, Benfield T, Fätkenheuer G, Kortepeter MG, Atmar RL, Creech CB, Lundgren J, Babiker AG, Pett S, Neaton JD, Burgess TH, Bonnett T, Green M, Makowski M, Osinusi A, Nayak S, Lane HC, ACTT-1 Study Group Members. Remdesivir for the Treatment of Covid-19 Preliminary Report. The New England journal of medicine. 2020

25. Wang, Yeming, Zhang, Dingyu, Du, Guanhua, Du, Ronghui, Zhao, Jianping, Jin, Yang, Fu, Shouzhi, Gao, Ling, Cheng, Zhenshun, Lu, Qiaofa, Hu, Yi, Luo, Guangwei, Wang, Ke, Lu, Yang, Li, Huadong, Wang, Shuzhen, Ruan, Shunan, Yang, Chengqing, Mei, Chunlin, Wang, Yi, Ding, Dan, Wu, Feng, Tang, Xin, Ye, Xianzhi, Ye, Yingchun, Liu, Bing, Yang, Jie, Yin, Wen, Wang, Aili, Fan, Guohui, Zhou, Fei, Liu, Zhibo, Gu, Xiaoying, Xu, Jiuyang, Shang, Lianhan, Zhang, Yi, Cao, Lianjun, Guo, Tingting, Wan, Yan, Qin, Hong, Jiang, Yushen, Jaki, Thomas, Hayden, Frederick G, Horby, Peter W, Cao, Bin, Wang, Chen. Remdesivir in adults with severe CoVID-19: a randomised, double-blind, placebo-controlled, multicentre trial. The Lancet. 2020;395(10236):1569-1578.

26. Spinner CD, Gottlieb RL, Criner GJ, Arribas López JR, Cattelan AM, Soriano Viladomiu A, Ogbuagu O, Malhotra P, Mullane KM, Castagna A, Chai LYA, Roestenberg M, Tsang OTY, Bernasconi E, Le Turnier P, Chang SC, SenGupta D, Hyland RH, Osinusi AO, Cao H, Blair C, Wang H, Gaggar A, Brainard DM, McPhail MJ, Bhagani S, Ahn MY, Sanyal AJ, Huhn G, Marty FM, GS-US-540-5774 Investigators. Effect of Remdesivir vs Standard Care on Clinical Status at 11 Days in Patients With Moderate COVID-19: A Randomized Clinical Trial. JAMA. 2020;

27. Peter Horby, Wei Shen Lim, Jonathan Emberson, Marion Mafham, Jennifer Bell, Louise Linsell, Natalie Staplin, Christopher Brightling, Andrew Ustianowski, Einas Elmahi, Benjamin Prudon, Christopher Green, Timothy Felton, David Chadwick, Kanchan Rege, Christopher Fegan, Lucy C Chappell, Saul N Faust, Thomas Jaki, Katie Jeffery, Alan Montgomery, Kathryn Rowan, Edmund Juszczak, J Kenneth Baillie, Richard Haynes, Martin J Landray, - RECOVERY 
medRxiv preprint doi: https://doi.org/10.1101/2020.09.27.20202754; this version posted September 28 , 2020. The copyright holder for this preprint (which was not certified by peer review) is the author/funder, who has granted medRxiv a license to display the preprint in

It is made available under a CC-BY-NC-ND 4.0 International license .

538

539

540

541

542

543

544

545

546

547

548

549

550

551

552

553

554

555

556

557

Collaborative Group. Effect of Dexamethasone in Hospitalized Patients with COVID-19: Preliminary Report. medRxiv. 2020;

28. Borah R, Brown AW, Capers PL, Kaiser KA. Analysis of the time and workers needed to conduct systematic reviews of medical interventions using data from the PROSPERO registry. BMJ Open. 2017 Feb 27;7(2):e012545. Available from: doi:10.1136/bmjopen-2016-012545

29. Shojania KG, Sampson M, Ansari MT, Ji J, Doucette S, Moher D. How quickly do systematic reviews go out of date? A survival analysis. Ann Intern Med. 2007 Aug 21;147(4):224-33. Available from: doi:10.7326/0003-4819-147-4-200708210-00179

30. Coronavirus and the risks of 'speed science' [Internet] Reuters; 2020 [Accessed 2020 April 12] Available from:https://www.weforum.org/agenda/2020/03/speed-science-coronaviruscovid19-research-academic

31. Kelly SE, Moher D, Clifford TJ. Quality of conduct and reporting in rapid reviews: an exploration of compliance with PRISMA and AMSTAR guidelines. Syst Rev. 2016 May 10;5:79. Available from: doi:10.1186/s13643-016-0258-9

32. Elliott JH, Synnot A, Turner T, Simmonds M, AkI EA, McDonald S, et al.; Living Systematic Review Network. Living systematic review: 1. Introduction-the why, what, when, and how. J Clin Epidemiol. 2017 Nov;91:23-30. Available from: doi:10.1016/j.jclinepi.2017.08.01

33. Akl EA, Haddaway NR, Rada G, Lotfi T. Evidence synthesis 2.0: when systematic, scoping, rapid, living, and overviews of reviews come together. J Clin Epidemiol. 2020 Mar 4. pii: S0895-4356(19)30986-2. Available from: doi:10.1016/j.jclinepi.2020.01.025 